Review

\title{
Preventing Diabetes - What Is the Potential of Daily Water Intake and Its Mineral Nutrients?
}

\author{
Johannes Naumann ${ }^{1, *}$, Diana Biehler ${ }^{1}$, Tania Lüty' ${ }^{1}$ and Catharina Sadaghiani ${ }^{1}$ \\ 1 Interdisciplinary Center for Treatment and Research in Balneology, Institute for Infection Prevention and \\ Hospital Epidemiology, Medical Center - University of Freiburg, Faculty of Medicine, University of \\ Freiburg, Freiburg 79106, Germany \\ * Correspondence: johannes.naumann@uniklinik-freiburg.de; Tel.: +49-761-270-82430
}

\begin{abstract}
To address the question whether there is evidence that drinking water in general or mineral water in particular is effective in preventing diabetes; we performed a literature search of randomized controlled trials (PubMed). The search resulted in very few trials $(\mathrm{N}=9)$ investigating this topic: one trial investigates the effect of increasing water consumption on glycemic control in diabetic patients; two trials investigate the effect of drinking water with a meal in diabetic patients; while six trials compare the effect of mineral rich water with that of low mineralized water on glucose metabolism in healthy subjects. There is evidence that increasing water consumption can improve glucose metabolism and randomized controlled trials with mineral water suggest that waters containing relevant amounts of magnesium can exert an additional effect. The role of bicarbonate; which is present in all the mineral waters used in the trials; will be discussed. Future research needs to investigate the effect of mineral water in prediabetic individuals or individuals with impaired glycemic control.
\end{abstract}

Keywords: diabetes; water intake; mineral water; magnesium; bicarbonate; review; prevention

\section{Introduction}

The incidence of type 2 diabetes mellitus, pre-diabetes, impaired glucose tolerance and metabolic syndrome has increased considerably worldwide. The global prevalence of diabetes is estimated to be $8.8 \%$, i.e. there are 415 million diabetics worldwide and 59.8 million diabetics in Europe $(9.1 \%$ ) alone. In Germany, $7.2 \%$ of males and $7.5 \%$ of females are affected by diabetes. Adding a further $2.1 \%$ for undetected cases, approximately $9.3 \%$ of the German population is affected [1]. In 2008, diabetes led to direct costs, i.e. costs for medication and medical fees, of 6.3 million Euros in Germany, with additional costs for non-productive time and invalidity pensions [2].

Making lifestyle changes is the most effective way to reduce the risk of developing diabetes by an estimated $34-43 \%$ [3]. Life style changes include a healthy diet and sufficient physical activity of $150 \mathrm{~min}$ a week, which should result in a weight loss of $7 \%$.

A healthy diet includes healthy drinking, because sugar sweetened beverages may add to excessive calorie intake, heightening the risk of obesity and associated diseases [4]. Increasing water consumption right before or during a meal curbs the appetite and reduces calorie intake [5].

Moreover, mineral nutrients such as bicarbonate and magnesium, in particular, are thought to affect glucose metabolism. An increased dietary acid load is associated with the development of insulin resistance [6] while a pre-existing diabetes favours acidosis, which, in turn, leads to increased insulin resistance [7].

This review explores to what extent drinking tap water or mineral water influences the risk for diabetes and impaired glucose tolerance. The results of the randomized controlled trials (RCTs) found through the literature search will be discussed alongside pathophysiological aspects as well as results from interventional studies using mineral nutrient supplements and animal trials. 


\section{Methods}

To evaluate the influence of water intake on glucose metabolism, we performed a systematic literature search from March 30th 2017 for RCTs in the PubMed database using the following terms:

(Diabetes OR impaired glucose tolerance OR insulin resistance) AND (Drinking water OR mineral water) AND (Randomized controlled trial OR Review OR Crossover).

RCTs and cross-over trials were included, if a parameter for glucose control was investigated (Figure 1). Only trials in English, German, Spanish and French were included.

\section{Measurement parameters (with normal values) for glycemic control}

Fasting glucose $(<110 \mathrm{mg} / \mathrm{dl})$

Glucose level $2 \mathrm{~h}$ after glucose loading $(<140 \mathrm{mg} / \mathrm{dl})$

Fasting insulin (6 - $25 \mathrm{mU} / 1)$

Insulin after glucose loading $(<200 \mathrm{mU} / \mathrm{l})$

HOMA-IR $(<2)$

Product of fasting insulin $[\mu \mathrm{U} / \mathrm{ml}] \times$ fasting glucose $[\mathrm{mg} / \mathrm{dl}]) / 405$

Measure for insulin resistance

Glycated hemoglobin, HbA1c ( 6 \%)

Percentage of glycated hemoglobin

Measure for blood glucose levels during the last 1 to 3 month

Glycoalbumin (11 \% - $16 \%)$

Percentage of glycosylated blood proteins

Measure for blood glucose levels in the last 2 to 4 weeks

Fructosamin $(200-290 \mu \mathrm{mol} / \mathrm{l})$

Result from glycation reactions between a sugar and a primary amine.

Measure for blood glucose levels in the last 1 to 3 weeks

Figure 1. Measurement parameters for glycemic control

\section{Results}

Our systematic literature search yielded 168 trials, 156 of which were excluded by two independent reviewers based on their titles, thus leaving twelve trials.

After reading the abstracts another seven trials were excluded:

a) three were not RCTs or cross - over trials ([8], [9], [10])

b) one trial compared alcoholic beverages and water [11]

c) three reviews investigated the correlation between water intake and its influence on body weight and health, but failed to cite RCTs on risk of diabetes or impaired glucose tolerance ([12], [13], [5]).

Therefore, three RCTs and two cross - over trials were left for review ([14], [15], [16], [17], [18]). 
After reviewing references four additional RCTs ([19], [20], [21], [22]) were included. Hence, nine trials were reviewed. Our search did not reveal a systematic review of RCTs dealing with our research objective. Of the trials screened, one examined the effect of increased water intake [18], two trials examined the immediate effect of drinking water with a meal ([14] ,[15]) (Table 1), six trials compared the effect of low mineralized water (tap water) with the effect of mineral rich water ([16],[17],[19],[20],[21],[22]) (Table 2, 3). All investigated mineral rich waters were bicarbonate rich waters.

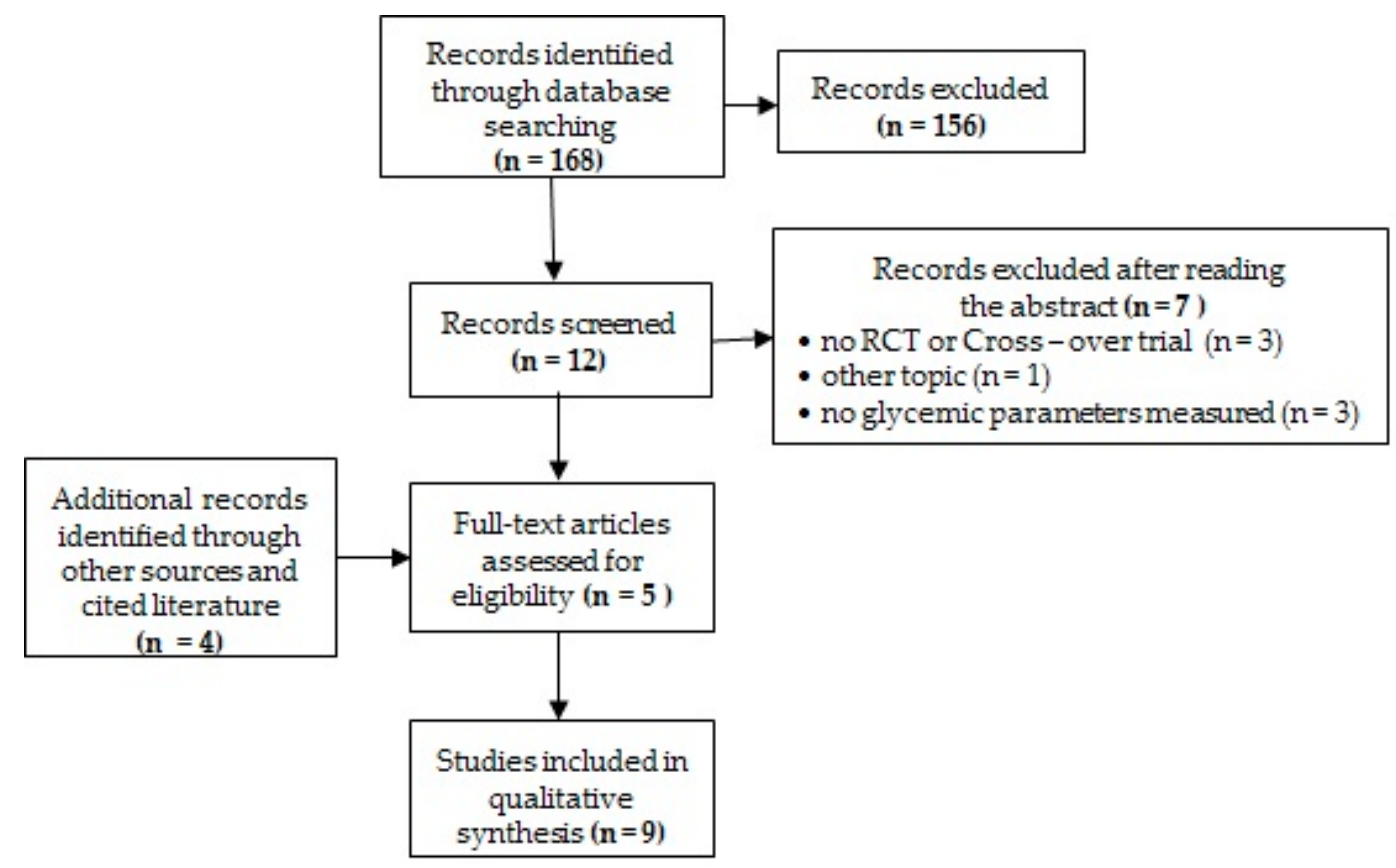

Figure 2. Flow-chart of the literature search 
Table 1. RCTs with tap water as intervention

\begin{tabular}{|c|c|c|c|c|}
\hline Study & Intervention & Participants & Parameters & Results \\
\hline $\begin{array}{l}\text { 2Madjd et al., } \\
2017 \text { [18] }\end{array}$ & $\begin{array}{l}\text { Single blind randomized study } \\
\text { Women participating in a } \\
\text { weight loss program did or did } \\
\text { not substitute one sugar } \\
\text { sweetened beverage (SSB) per } \\
\text { day with for } 24 \text { weeks. }\end{array}$ & $\begin{array}{l}81 \text { overweight and } \\
\text { obese women with } \\
\text { type } 2 \text { diabetes } \\
\text { between } 18 \text { and } 50 \\
\text { years }\end{array}$ & $\begin{array}{l}\text { Body weight, } \\
\text { fasting insulin, } \\
\text { insulin sensitivity, } \\
\text { glucose tolerance }\end{array}$ & $\begin{array}{c}\text { Women in both groups lost weight and improved their } \\
\text { glycemic control. Women who substituted one SSB with } \\
\text { water had significant weight loss } \\
\text { lost more weight } \\
\text { had a lower fasting insulin } \\
\text { had better insulin sensitivity } \\
\text { and were better in the glucose tolerance test } \\
\text { compared to the control group after } 24 \text { weeks. }\end{array}$ \\
\hline $\begin{array}{c}{ }^{1} \text { Torsdottir et al., } \\
1989[14]\end{array}$ & $\begin{array}{l}\text { Crossover trial. After overnight } \\
\text { fasting, participants were } \\
\text { served a meal with or without } \\
\quad 300 \mathrm{ml} \text { of water. }\end{array}$ & $\begin{array}{l}7 \text { healthy adults and } 20 \\
\text { patients with type } 2 \\
\text { diabetes }\end{array}$ & $\begin{array}{l}\text { Postprandial } \\
\text { glucose and insulin } \\
\text { response }\end{array}$ & $\begin{array}{l}\text { In healthy and well-controlled diabetic patients peak blood } \\
\text { glucose increased significantly. In healthy subjects serum } \\
\text { insulin and overall blood glucose response also increased } \\
\text { with addition of water. } \\
\text { In poorly-controlled diabetic patients, however, the } \\
\text { addition of water did not display significant effects. }\end{array}$ \\
\hline $\begin{array}{l}{ }^{1} \text { Gregerson et al., } \\
1990 \text { [15] }\end{array}$ & $\begin{array}{l}\text { Crossover trial. Participants } \\
\text { were served a meal with } 90 \mathrm{ml} \\
\text { or } 600 \mathrm{ml} \text { of water, respectively. } \\
\text { The meal with } 90 \mathrm{ml} \text { was eaten } \\
\text { in either } 10 \mathrm{~min} \text { or } 30 \mathrm{~min} .\end{array}$ & $\begin{array}{c}10 \text { patients with type } 2 \\
\text { diabetes }\end{array}$ & $\begin{array}{l}\text { Postprandial } \\
\text { glucose and insulin } \\
\text { response }\end{array}$ & $\begin{array}{c}\text { Neither the amount of water nor the duration of the meal } \\
\text { had a significant effect on glycemic and insulinemic } \\
\text { response. }\end{array}$ \\
\hline
\end{tabular}

${ }^{1}$ study investigating immediate effects; ${ }^{2}$ studies investigating medium-term effects. 
Table 2. Crossover trials comparing the effects of bicarbonate rich mineral water with tap water

\begin{tabular}{|c|c|c|c|c|c|}
\hline Study & Intervention & Water composition & Participants & Parameters & Results \\
\hline $\begin{array}{l}\text { 1Schoppen et al., } \\
2007 \text { [17] }\end{array}$ & $\begin{array}{l}\text { 3 - way randomized } \\
\text { crossover study, where } 3 \\
\text { waters were tested by } \\
\text { drinking } 0.51 \text { with a } \\
\text { standardized meal. } \\
\text { Glycemic parameters were } \\
\text { measured up to } 120 \text { min } \\
\text { postprandial. }\end{array}$ & 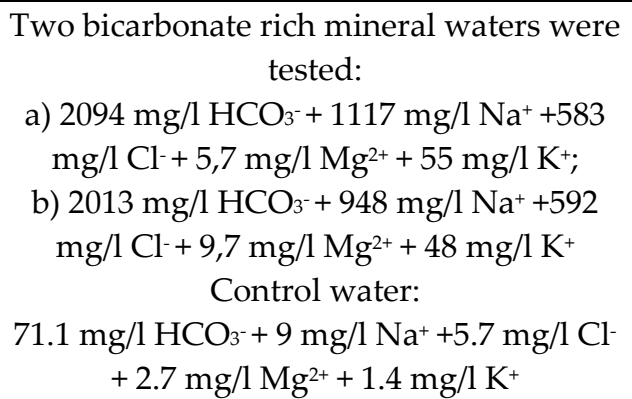 & $\begin{array}{l}18 \text { healthy } \\
\text { postmenopausal } \\
\text { women aged } 51 \text { to } \\
59\end{array}$ & $\begin{array}{l}\text { Postprandial blood } \\
\text { glucose - and insulin } \\
\text { concentration }\end{array}$ & $\begin{array}{l}\text { Drinking one of the two } \\
\text { bicarbonate rich mineral } \\
\text { waters resulted in } \\
\text { significantly lower insulin } \\
\text { concentrations at } 120 \text { min } \\
\text { after the meal. } \\
\text { No differences in glucose } \\
\text { concentration were found. }\end{array}$ \\
\hline $\begin{array}{l}\text { 2Toxqui et al., } \\
2016 \text { [16] }\end{array}$ & $\begin{array}{l}\text { Randomized controlled } \\
\text { single-blinded crossover } \\
\text { trial. For } 8 \text { weeks } 11 \text { of the } \\
\text { test water was drunk? daily } \\
\text { followed by an } 8 \text {-week } \\
\text { washout period before } \\
\text { testing the control water }\end{array}$ & $\begin{array}{c}\text { Bicarbonate rich test water: } 2050 \mathrm{mg} / \mathrm{l} \\
\mathrm{HCO}_{3^{-}}+1090 \mathrm{mg} / \mathrm{l} \mathrm{Na}^{+}+622 \mathrm{mg} / \mathrm{C} \mathrm{Cl}^{-}+5.8 \\
\mathrm{mg} / \mathrm{l} \mathrm{Mg}^{2+} \\
\text { Control water: } 75 \mathrm{mg} / \mathrm{l} \mathrm{HCO}^{-}+7.6 \mathrm{mg} / \mathrm{l} \\
\mathrm{Na}^{+}+4.8 \mathrm{mg} / 1 \mathrm{Cl}^{-}+2.8 \mathrm{mg} / 1 \mathrm{Mg}^{2+}\end{array}$ & $\begin{array}{l}72 \text { healthy adults } \\
\text { aged } 18 \text { to } 45, \text { with } \\
\text { moderately elevated } \\
\text { cholesterol levels }\end{array}$ & $\begin{array}{l}\text { Fasting glucose and } \\
\text { fasting insulin }\end{array}$ & $\begin{array}{l}\text { Drinking both waters } \\
\text { resulted in a significant } \\
\text { reduction of fasting } \\
\text { glucose and LDL - } \\
\text { cholesterol. }\end{array}$ \\
\hline $\begin{array}{l}\text { 2Pérez-Granados } \\
\text { et al., } 2010 \text { [21] }\end{array}$ & $\begin{array}{l}\text { Controlled crossover trial. } \\
\text { For } 8 \text { weeks } 11 \text { of the test } \\
\text { water daily with an } 8 \text {-week } \\
\text { washout period before } \\
\text { testing the control water }\end{array}$ & $\begin{array}{c}\text { Bicarbonate rich test water: } 2120 \mathrm{mg} / \mathrm{l} \\
\mathrm{HCO}_{3}^{-}+1102 \mathrm{mg} / \mathrm{l} \mathrm{Na}^{+}+597 \mathrm{mg} / \mathrm{l} \mathrm{Cl}^{-}+9.4 \\
\mathrm{mg} / \mathrm{l} \mathrm{Mg}^{2+} \\
\text { control water: } 104 \mathrm{mg} / 1 \mathrm{HCO}^{-}+8.7 \mathrm{mg} / \mathrm{l} \\
\mathrm{Na}^{+}+11 \mathrm{mg} / \mathrm{l} \mathrm{Cl}^{-}+5.0 \mathrm{mg} / \mathrm{l} \mathrm{Mg}^{2+}\end{array}$ & $\begin{array}{l}18 \text { healthy adults } \\
\text { aged } 18 \text { to } 40, \text { with } \\
\text { moderately elevated } \\
\text { cholesterol levels }\end{array}$ & $\begin{array}{l}\text { Fasting glucose and } \\
\text { fasting insulin }\end{array}$ & $\begin{array}{l}\text { Compared to control water } \\
\text { fasting glucose decreased } \\
\text { with the bicarbonate rich } \\
\text { water but not significantly } \\
\qquad(\mathrm{p}=0.056) .\end{array}$ \\
\hline $\begin{array}{l}\text { Schorr, } 1996 \\
{[22]}\end{array}$ & $\begin{array}{l}\text { Randomized, } \\
\text { placebo-controlled, double } \\
\text { blind crossover trial. For } 4 \\
\text { weeks } 1.5 \text { l of the test water } \\
\text { with a } 2 \text {-week washout } \\
\text { period before testing the } \\
\text { control water }\end{array}$ & $\begin{array}{c}\text { Bicarbonate rich test waters: } \\
\text { a) } 879 \mathrm{mg} / \mathrm{l} \mathrm{HCO} 3^{-}+1295 \mathrm{mg} / \mathrm{l} \mathrm{Na}^{+}+1507 \\
\mathrm{mg} / \mathrm{l} \mathrm{Cl}^{-}+9.7 \mathrm{mg} / 1 \mathrm{Mg}^{2+} \\
\text { b) } 1983 \mathrm{mg} / 1 \mathrm{HCO}^{-}+602 \mathrm{mg} / \mathrm{l} \mathrm{Na}^{+}+152 \\
\mathrm{mg} / \mathrm{l} \mathrm{Cl}^{-}+53 \mathrm{mg} / 1 \mathrm{Mg}^{2+} \\
\text { control water: }<0.2 \mathrm{mmol} / 1 \mathrm{HCO}^{-}+<0.1 \\
\mathrm{mmol} / 1 \mathrm{Na}^{+}+<0.1 \mathrm{mmol} / \mathrm{Cl}^{-}+<0.1 \\
\mathrm{mmol} / \mathrm{Mg}^{2+}\end{array}$ & $\begin{array}{c}21 \text { healthy adults } \\
\text { between } 60 \text { and } 72 \\
\text { years }\end{array}$ & $\begin{array}{l}\text { Plasma glucose, } \\
\text { plasma insulin and } \\
\text { glucose tolerance }\end{array}$ & $\begin{array}{l}\text { No significant effect was } \\
\text { found. }\end{array}$ \\
\hline
\end{tabular}

${ }^{1}$ study investigating immediate effects; ${ }^{2}$ studies investigating medium-term effects. 
Table 3. Controlled trials comparing the effects of bicarbonate and magnesium rich mineral water with tap water

\begin{tabular}{|c|c|c|c|c|c|}
\hline Study & Intervention & Water composition & Participants & Parameters & Results \\
\hline $\begin{array}{c}\text { Gutenbrunner, } \\
1993 \text { [19] }\end{array}$ & $\begin{array}{l}\text { Randomized, controlled, } \\
\text { single blind trial. For } 28 \\
\text { days, participants drank } \\
1.4 \text { l daily of a bicarbonate } \\
\text { and magnesium rich } \\
\text { water or control water. }\end{array}$ & $\begin{array}{c}\text { Bicarbonate and magnesium } \\
\text { rich water: } 2946 \mathrm{mg} / \mathrm{l} \mathrm{HCO}^{-}+ \\
967 \mathrm{mg} / 1 \mathrm{Na}^{+}+128 \mathrm{mg} / \mathrm{l} \mathrm{Cl}^{-}+ \\
102 \mathrm{mg} / \mathrm{l} \mathrm{Mg}^{2+} \\
\text { control water: } 150 \mathrm{mg} / 1 \mathrm{HCO}_{3}{ }^{-} \\
+19.8 \mathrm{mg} / 1 \mathrm{Na}^{+} \text {(magnesium } \\
\text { concentration is not } \\
\text { mentioned) }\end{array}$ & $\begin{array}{c}24 \text { healthy men } \\
\text { between } 19 \text { and } 31 \\
\text { years }\end{array}$ & $\begin{array}{l}\text { Fasting glucose } \\
\text { fasting insulin } \\
\text { glucose tolerance } \\
\text { serum fructosamin }\end{array}$ & $\begin{array}{l}\text { Men drinking the bicarbonate } \\
\text { and magnesium rich water had } \\
\text { significantly lower serum } \\
\text { concentrations of fructosamin } \\
\text { and glucose concentrations } 30 \\
\text { min after glucose loading } \\
\text { compared to men drinking } \\
\text { control water. }\end{array}$ \\
\hline $\begin{array}{l}\text { Murakami et } \\
\text { al., } 2015 \text { [20] }\end{array}$ & $\begin{array}{c}\text { Controlled crossover trial. } \\
\text { Participants drank } 0,51 \text { of } \\
\text { each water for one week } \\
\text { in two cycles. The } \\
\text { intervention lasted } 4 \\
\text { weeks: } \\
\text { CW/BMW/CW/BMW }\end{array}$ & 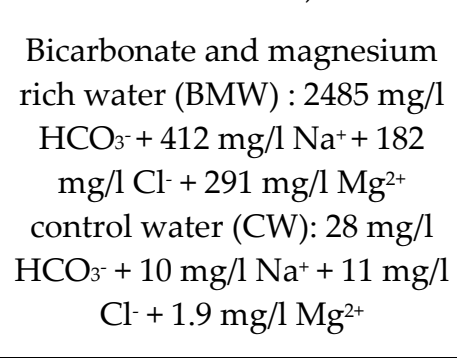 & $\begin{array}{c}19 \text { healthy adults } \\
\text { between } 26 \text { and } 59 \\
\text { years }\end{array}$ & $\begin{array}{l}\text { Fasting plasma } \\
\text { glucose } \\
\text { serum glucose } \\
\text { insulin } \\
\text { glycoalbumin }\end{array}$ & $\begin{array}{l}\text { After the periods of drinking } \\
\text { bicarbonate and magnesium } \\
\text { rich water, glycoalbumin } \\
\text { concentrations were } \\
\text { significantly lower. } \\
\text { No differences were found for } \\
\text { glucose and insulin } \\
\text { concentrations. }\end{array}$ \\
\hline
\end{tabular}




\section{Discussion}

\subsection{Effect of water intake}

\subsubsection{Effect of increased water intake}

The effect of water intake on glucose metabolism and body weight was investigated in a single-blinded randomized trial in 62 obese women, who participated in a weight loss program for 24 week [18] (Table 1). One half of the participating women replaced diet drinks with water. Women in both groups lost weight and improved their glucose metabolism. However, the effect in the group of women substituting diet drinks with water was significantly higher. The substitution group had more substantial weight loss, a lower insulin concentration, lower insulin resistance and lower glucose concentration $2 \mathrm{~h}$ after food intake. Hence, substitution of diet drinks with water showed a positive influence on glucose metabolism.

Two observational studies examined the relationship between water intake and hyperglycaemia (defined as an elevated blood sugar level) or diabetes risk, respectively. During a nine-year follow-up 565 of 3,615 participants developed hyperglycaemia, whereas 202 of 3,615 participants (male \& female) developed diabetes [23]. The risk of hyperglycaemia was significantly lower $(20-30 \%)$ in participants drinking more than 0.51 of water daily compared with drinking less. In this study, as well as in the following, the increase in water intake was significantly correlated with decreased intake of sugary and alcoholic beverages. Comprising a 13-year follow up, the second study was not able to show a significant correlation between water intake and diabetes risk. Yet, the authors calculated that daily substitution of one sugar-sweetened drink for water decreases the diabetes risk by $7 \%$ [24].

One cross-sectional study calculated a type 2 diabetes risk score for 138 healthy adults taking into account age, gender, BMI, waist circumference, ethnicity and family history regarding diabetes and blood pressure and correlated it with the participant's daily water intake. An increase of $240 \mathrm{ml}$ in water intake revealed a significant decline in the type 2 diabetes risk score [9]. All of the four groups formed based on their diabetes risk score had a daily fluid intake of 2.51 . The ratio of water intake to liquid intake increased with a lower diabetes risk score.

A nutrition survey examined the relationship between the quantity of water taken in and $\mathrm{HbA} 1 \mathrm{c}$ in 1,035 participants. In male participants with $\mathrm{HbAc1}<5.5 \%$, the proportion of water to total liquid intake was significantly higher (17\% and $10 \%$ respectively) than in males with $\mathrm{HbA} 1 \mathrm{c}>$ $5.5 \%$. Based on this finding, the authors calculated that an increase of $240 \mathrm{ml}$ in daily water intake reduces the risk of elevated $\mathrm{HbAc1}>5.5 \%$ by $22 \%$ in men but not in women [25].

In summary, this indicates that sufficient water intake reduces diabetes risk. This may be due to concomitant dietary habits. An observational study in the USA comprising 18,311 participants showed that a higher water intake was accompanied by a decrease in total intake of calories, sugary beverages, total fat, saturated fats, sugar, sodium and cholesterol [26]. This effect was greater in males under the age of 65 .

Conversely, a survey of 75 countries showed that a $1 \%$ rise in soft drink consumption was associated with an additional 0.3 adults per 100 adults developing diabetes [27].

\subsubsection{Effect of drinking water with a meal}

Two RCTs investigated the postprandial glycemic effect of drinking water with a meal (Table 1). One study with non-insulin dependent diabetic patients compared the effect of drinking $90 \mathrm{ml}$ of tap water and $600 \mathrm{ml}$ of tap water with a meal on postprandial glucose and insulin [15]. Neither the volume of ingested water nor the consumption time of the meal (10 vs. $30 \mathrm{~min}$ ) showed an effect.

The other RCT compared the postprandial glycemic response after a meal taken with or without $300 \mathrm{ml}$ of tap water [14]. In seven healthy and twelve well-controlled diabetic patients, peak blood glucose increased significantly. In healthy subjects serum insulin and overall blood glucose response also increased with the addition of water. Conversely, in poorly-controlled diabetic patients, the addition of water did not yield significant effects. 
The effect is possibly attributed to acceleration of the gastric emptying rate of carbohydrates with the addition of even as little as $90 \mathrm{ml}$ of water,

\subsection{Effect of mineral rich water}

All trials comparing the effect of tap water and mineral water used bicarbonate-rich mineral water, since a high dietary acid load is associated with increased insulin resistance as well as with disturbed glucose metabolism. The following section highlights some studies investigating the effect of bicarbonate on glucose control.

A recent intervention study [28] in diabetic patients with chronic kidney disease showed that compared with a placebo, supplementation with bicarbonate targeting a serum concentration of $24-$ $28 \mathrm{mmol} / \mathrm{l}$ significantly improved multiple parameters of glucose metabolism. For example, the serum glucose concentration decreased from $127 \mathrm{mg} / \mathrm{dl}$ to $110 \mathrm{mg} / \mathrm{dl}$, the proportion of glycated haemoglobin declined from 7.7 to $6.7 \%$, insulin resistance (HOMA-IR) decreased from 6.1 to 7.0 , and serum insulin concentration decreased from $13.4 \mathrm{mcIU}$ to $19.9 \mathrm{mcIU}$. Insulin resistance declined up to a bicarbonate concentration of $28 \mathrm{mmol} / \mathrm{l}$, however, it increased when $28 \mathrm{mmol} / \mathrm{l}$ of bicarbonate was exceeded. . Thus, the improvement in insulin resistance was based on a correction of acidosis rather than on the serum bicarbonate concentration itself. Mild acidosis is accompanied by increased insulin resistance even in healthy subjects.

A cross-sectional study [29] investigated the relationship between serum hydrogen carbonate concentration and insulin resistance in 1,496 healthy adults. Participants with lower serum hydrogen bicarbonate concentration showed both significantly increased insulin resistance and a significantly elevated serum insulin concentration. This effect was even more distinct in participants with higher BMI. Similarly, a recent study [6] revealed a relationship between an increased lactate concentration, which is an indicator for mild metabolic acidosis, and insulin resistance in 104 sedentary adults.

The relevance of serum hydrogen carbonate in prevention was reported in a prospective study in 630 women ( $\varnothing=56$ years) and a 10-year follow up. Women with lower serum hydrogen carbonate concentrations had a significant higher risk of developing type 2 diabetes than women with higher serum hydrogen carbonate concentrations [30].

\subsubsection{Effect of bicarbonate-rich water}

The studies investigating the effect of mineral-rich water on glucose metabolism were conducted in healthy individuals (Table 2). Two studies focused on fat metabolism examined participants with moderately increased cholesterol levels ([16],[21]). All six studies in this section used mineral water rich in bicarbonate, two of which contained additional substantial magnesium concentrations ([19], [20]). One of these studies dealt with temporary effects [17] whereas the other five studies investigated the effects after several days or weeks ([16],[19],[20],[21],[22]).

Five studies ([16],[19],[20],[21],[22]) examined fasting blood glucose and fasting insulin levels. One of these studies additionally reported serum fructosamin concentrations and conducted glucose tolerance tests [19], while another study also measured the plasma glycoalbumin concentration [20].

An RCT investigated the temporary effect of drinking 0.51 of two bicarbonate-rich mineral waters as compared to drinking water low in minerals [17]. Eighteen healthy, postmenopausal women consumed a standard meal accompanied by 0.51 of one the three waters. Two hours after the meal, no significant differences in glucose concentrations were observed between the groups. Only one of the two bicarbonated mineral waters induced a significantly lower insulin concentration 120 min after the meal and a significantly higher insulin peak after $30 \mathrm{~min}$. However, this effect was only observed in four women with the lowest insulin sensitivity.

An RCT with cross-over design in 64 participants compared the intake of bicarbonate-rich mineral water with a mineral water low in minerals [16]. Drinking of both waters resulted in a significant decrease of the glucose concentration, total cholesterol and LDL-cholesterol. This effect was mainly attributed to an increased water intake $(1 \mathrm{l} /$ day for 8 weeks, two 8-week intervention phases with an 8 week wash-out phase in between) associated with a reduced calorie intake from beverages, especially sugary beverages. Nevertheless, reduction of the glucose concentration after 
drinking the bicarbonated mineral water was more distinct (control water: Baseline: $4.9 \mathrm{mmol} / \mathrm{l}$; after water drinking: $4.88 \mathrm{mmol} / \mathrm{l}$ and bicarbonated water: Baseline: $4.95 \mathrm{mmol} / \mathrm{l}$; after water drinking: $4.8 \mathrm{mmol} / \mathrm{l})$. A decrease in glucose concentration was not observed for either of the two waters.

Another RCT with a similar design in 18 participants compared the effect on fat and glucose metabolism of a bicarbonated water $\left(2120 \mathrm{mg} / \mathrm{l} \mathrm{HCO}^{-}+9.4 \mathrm{mg} / \mathrm{l} \mathrm{Mg}^{2+}\right)$ with a water low in minerals (104 mg/l $\left.\mathrm{HCO}_{3}{ }^{-}+5.0 \mathrm{mg} / \mathrm{l} \mathrm{Mg}^{2+}\right)$ [21]. Significant differences were not observed between the two waters. However, fasting blood glucose was lower after drinking bicarbonated water than after drinking water low in minerals $(\mathrm{p}=0.056)$. Besides, drinking both waters induced a reduction of the insulin concentration (Baseline: $8.8 \pm 4.1 \mathrm{mU} / \mathrm{l}$, low mineral water: $8.2 \pm 2.6 \mathrm{mU} / \mathrm{l}$, bicarbonate water: $7.7 \pm 4.3 \mathrm{mU} / \mathrm{l})$.

Likewise, in another RCT [22] comparing the possible influence of a water low in minerals with both a water high in sodium bicarbonate and a water high in sodium chloride on blood pressure in healthy subjects eating a diet low in sodium there were no differences in either insulin nor glucose concentration.

These studies do not show a significant difference between the influence of water rich in minerals and water low in minerals on glucose and insulin concentration.

\subsubsection{Effect of bicarbonate and magnesium rich water}

The following two studies tested mineral water containing not only bicarbonate but also substantial magnesium concentrations (> $100 \mathrm{mg} / \mathrm{l})$. They also determined the long-term blood sugar concentration (fructosamine or glycoalbumin concentration). One study additionally conducted a glucose tolerance test (Table 3).

In 1993, Gutenbrunner et al. [19] conducted a 4-week randomized and blinded mineral water cure in 24 healthy males. Participants received 1.41 daily of either a water rich in hydrogen carbonate $\left(2946 \mathrm{mg} / \mathrm{l} \mathrm{HCO}_{3}{ }^{-}+102 \mathrm{mg} / \mathrm{l} \mathrm{Mg}^{2+}\right)$ or tap water $\left(150 \mathrm{mg} / \mathrm{l} \mathrm{HCO}_{3^{-}}, \mathrm{N} / \mathrm{A} \mathrm{Mg}^{2+}\right.$. Compared with tap water, after a glucose tolerance test, blood glucose concentrations declined significantly in the group receiving the water with hydrogen carbonate. This effect was still seen two days after the mineral water cure. Even the serum fructosamine concentration only declined in participants drinking mineral water high in hydrogen carbonate.

In a recent RCT [20] 19 healthy participants received $500 \mathrm{ml}$ of bicarbonate-rich mineral water $\left(2485 \mathrm{mg} / 1 \mathrm{HCO}_{3}{ }^{-+} 291 \mathrm{mg} / \mathrm{l} \mathrm{Mg}^{2+}\right)$ for one week. The intervention period lasted one week, followed by a wash-out period with $500 \mathrm{ml}$ tap water $\left(28 \mathrm{mg} / \mathrm{l} \mathrm{HCO}_{3}+1.9 \mathrm{mg} / \mathrm{l} \mathrm{Mg}^{2+}\right)$ daily. Both procedures were repeated once. Similarly to previously mentioned studies, there were no significant differences in glucose concentration or insulin concentrations after drinking either of the waters. However, the concentrations tended to be lower after drinking the bicarbonate-rich mineral water. Indeed, after drinking the bicarbonate-rich water glycoalbumin concentrations decreased significantly.

Again, this study showed a significant decrease in the glycoalbumin concentration even after the first week of intervention with tap water compared to baseline, indicating that water intake alone had an effect. Additionally, the bicarbonate rich water had a significant effect.

Significant effects were only seen in trials measuring long-term blood glucose levels. This indicates that individual measurements in healthy participants do not differ significantly, but slight differences add up over time to measurable differences. In patients suffering from pre-diabetes, diabetes or metabolic syndrome one would expect a positive influence on the glucose and insulin concentrations. Yet, not a single study investigated the influence of mineral water on glucose metabolism in a group of afflicted/diseased subjects.

However, rats suffering from metabolic syndrome induced by fructose administration were used to compare the effect of drinking mineral-rich and bicarbonate-rich water to water with low mineral content. 


\subsubsection{Effect of mineral rich water in an animal model}

It is known that rats receiving $10 \%$ fructose in their drinking water develop symptoms of metabolic syndrome and that the plasma glucose level increases considerably.

If fructose is administered in mineral water rather than tap water, the basic parameters of glucose metabolism e.g. glucose, insulin and triglyceride concentrations do not deteriorate at all or at least less [31]. Similarly, rats receiving fructose in tap water showed a strong increase in aldosterone level, whereas rats receiving fructose in mineral water had the same level as the control rats that did not receive any fructose. A review from 2016 [32] describes the relationship between elevated aldosterone level and both metabolic syndrome and type 2 diabetes.

Sirt1 and PGC1- $\alpha$ are proteins that counteract metabolic syndrome and aberrant glucose metabolism. Sirt1 positively influences multiple steps in glucose metabolism in the liver, the pancreas, muscles, and adipose tissue. De-acetylated PGC1- $\alpha$ is the main regulator of the sirt1 pathway [33], [34]. The expression of both proteins was significantly higher in liver tissue of rats receiving mineral water compared to rats receiving tap water [35]. Besides, the amount of phosphorylated insulin receptor substrate (IRS), the active form of the substrate that forwards the insulin signal, was elevated in liver tissues of rats receiving mineral water compared with rats receiving tap water [36]. This indicates increased insulin sensitivity. Though, both groups of rats taking in fructose had a lower level of phosphorylated IRS compared with control rats. This might be due to the fact that the serum magnesium concentration in rats receiving fructose significantly declined (1.71 $\mathrm{mmol} / \mathrm{l}$ and $1.55 \mathrm{mmol} / \mathrm{l}$ respectively) [31].

Magnesium ions are essential for the auto-phosphorylation of the insulin receptor, as two magnesium ions bind the tyrosine kinase domain. Disruption of phosphorylation is considered the main mechanism leading to insulin resistance through lack of magnesium ions [37].

In summary, these animal experiments suggest that intake of mineral water in patients with either metabolic syndrome, pre-diabetes, or type 2 diabetes might have a positive influence.

Besides bicarbonate, magnesium seems to be important. Both RCTs studying effects of mineral water rich in magnesium determined long-term blood glucose concentrations. Hence, the positive effect observed in these studies cannot be traced back exclusively to magnesium. Still, the currently available data indicate a positive influence of magnesium on the glucose metabolism and one might assume that magnesium absorbed from mineral waters also positively influences glucose metabolism.

\subsection{Clinical trials considering magnesium}

Results from studies investigating mineral waters containing relevant concentrations of magnesium are consistent with the results from studies investigating magnesium supplementation or intake of dietary magnesium. The latter demonstrated that in subjects suffering from magnesium deficiency, pre-diabetes, or insulin resistance, additional magnesium intake may ameliorate their glucose metabolism. Indeed, in $51 \%$ of the subjects suffering from magnesium deficiency and pre-diabetes, magnesium supplementation of $382 \mathrm{mg} /$ day positively influenced glucose metabolism compared to $7 \%$ of the subjects in a placebo group [38]. In adults with low insulin sensitivity magnesium supplementation of $365 \mathrm{mg} /$ day caused the serum glucose level to drop significantly and increased insulin sensitivity [39].

The most recent systematic review from 2016 including a meta-analysis of 21 randomized studies in 1,362 participants (684 individuals in $\mathrm{Mg}^{2+}$ group and 678 individuals in control group) compared the influence of magnesium supplementation on insulin sensitivity and glucose metabolism in diabetic individuals with the influence in non-diabetic individuals [40]. This review demonstrated significant amelioration of insulin resistance in both diabetic and non-diabetic individuals. A significant reduction of the serum glucose concentration was observed in a subset of studies including only those with supplementation for at least four months and only considering participants with magnesium deficiency.

4.3.1. Magnesium blood concentration 
In 2012 [41], a case control study in 200 obese individuals revealed that the 50 diabetics had a lower serum magnesium concentration than the 150 participating non-diabetics. Forty-eight per cent of the diabetics had magnesium deficiency compared with only $15 \%$ of the non-diabetics. Furthermore, a lower magnesium concentration was associated with a higher plasma glucose level, higher insulin resistance and a higher $\mathrm{HbAc1}$ concentration.

A prospective study explored this relationship in 8,555 participants with a follow-up period of 5.7 years [42] A reduction in the serum magnesium concentration of $0.1 \mathrm{mmol}$ was associated with an $18 \%$ higher risk of developing diabetes $(\mathrm{HR}=1.18 ; 95 \% \mathrm{CI}=1.04-1.33)$ and a $12 \%$ higher risk for pre-diabetes $(\mathrm{HR}=1.12 ; 95 \% \mathrm{CI}=1.01-1.25)$. In participants deficient in magnesium, the diabetes risk increased by $79 \%(\mathrm{HR}=1.79 ; 95 \% \mathrm{CI}=1.16-2.77)$ and the pre-diabetes risk increased by $44 \%(\mathrm{HR}=1.44 ; 95 \% \mathrm{CI}=0.91-2.27)$, however, the latter finding was not significant.

\subsubsection{Dietary magnesium}

In 2011, a review with meta-analysis of 13 prospective studies in a total of 536,318 participants and 24,516 diabetes cases [43] showed a significantly reduced risk for type 2 diabetes: Increasing the daily magnesium intake by $100 \mathrm{mg}$ was accompanied by a decrease in diabetes risk by $14 \%$.

The most recent meta-analysis (Fang et al., 2016) of 25 prospective studies comprising 637,922 participants revealed the following dose - effect - correlation: An increase of daily magnesium intake by $100 \mathrm{mg}$ was associated with an $8-13 \%$ lower diabetes risk [44].

Another meta-analysis including 6 cross-sectional studies in a total of 24,473 participants investigated the correlation between magnesium intake and metabolic syndrome [45]. This study revealed that daily intake of $100 \mathrm{mg}$ magnesium was associated with a risk reduction by $17 \%$.

\subsubsection{Relevance of magnesium for glucose metabolism}

A review by Gommers et al., 2016 [37] summarizes the multiple functions of magnesium on a molecular level. Another narrative review by Mooren, 2015 [46] sums up the molecular mechanisms and links them to data from clinical trials.

The binding of insulin to its receptor triggers a signalling cascade leading to import of glucose into the cell (muscle), to glycogen synthesis (liver) and lipid synthesis (adipose tissue). If this signalling cascade is impaired, more insulin is released into the bloodstream. When the increased amount of insulin is in the end also unable to trigger the signalling cascade sufficiently, blood sugar levels eventually rise.

Magnesium plays a direct role in the signalling cascade as a co-factor of the insulin receptor. Magnesium binds to the intracellular domain of the insulin receptor thereby allowing or enhancing transmission of the insulin signal induced by the extracellular binding of insulin to the receptor. Hence, magnesium increases insulin sensitivity.

It is known from studies in mice, that oral magnesium supplementation increases the number of glucose transporters in the cell membrane of muscle cells; , glucose can therefore be imported faster and more effectively [47].

An inflammatory environment also contributes to development of insulin resistance and is one of the main reasons for an obesity-related elevated diabetes risk. Thus, magnesium as an anti-inflammatory ion can counteract insulin resistance [48].

To prevent diabetes it is essential to preserve the function of $\beta$-cells [49]. A prospective study comprising 228 patients with disturbed glucose tolerance showed that the diabetes risk was smallest in participants with functioning $\beta$-cells at the beginning of the study [50]. The function of the $\beta$-cells was the strongest predictor for diabetes. In diabetic and non-diabetic participants, magnesium administration in the form of $\mathrm{MgCl}_{2}$ increased the function of $\beta$-cells [51].

Insulin also influences kidney cells to increase re-absorption of magnesium. After binding of insulin to its receptor, TRPM6 is recruited to the plasma membrane; consequently, magnesium re-absorption is enhanced [52]. Therefore, insulin resistance leads to increased magnesium excretion starting a vicious cycle.

Most of the glucose ingested from food is absorbed into muscles. Deteriorated insulin resistance inhibits absorption into the muscles, whereby the reason for deterioration may either be magnesium deficiency or acidosis, in which bicarbonate might be an issue. 
6 of 16

\section{Limitations}

The main limitation of this review is the small number of RCTs investigating the impact of mineral water on glucose metabolism. Furthermore, the studies had small numbers of participants and were carried out in healthy subjects thereby limiting the evidence for treatment of type 2 diabetes.

Nevertheless, existing observational studies, studies with animal models and interventional studies of minerals present in mineral waters suggest a probable positive effect of drinking water and especially mineral water on glucose metabolism.

\section{Conclusions}

Water is an ideal calorie-free and sugar-free beverage, which seems suitable to contribute to the reduction of the growing prevalence of type 2 diabetes and its pre-stages, as already recommended by several institutions such as the ADA [3] and the WHO [53].

Besides, drinking mineral water rich in bicarbonate and magnesium is an ideal addition to magnesium from food.

Due to the complexity of nutrition and the fact that studies investigating diabetes and nutrition often omit beverages, there are insufficient data to prove an association between intake of water, particularly bicarbonate or magnesium-rich mineral water and reduction in risk for diabetes.

Based on the reviewed pathophysiological data from trials in humans and animals and the epidemiological data, it can be assumed that drinking water or mineral water rich in magnesium and bicarbonate ameliorates glucose metabolism and reduces the risk of developing diabetes. Especially drinking mineral water for a longer period of time may have a positive effect.

Although the data are still inconclusive, from our point of view, drinking water or mineral rich water should be recommended to prevent and treat type 2 diabetes because of the absence of adverse effects.

Due to the high prevalence, the associated suffering and the resulting health expenditures, it is imperative to conduct RCTs to clarify the role of mineral water in prevention and treatment of diabetes.

Acknowledgments: The article processing charge was funded by the German Research Foundation (DFG) and the Albert Ludwigs University Freiburg in the funding program Open Access Publishing.

Author Contributions: Johannes Naumann and Diana Biehler performed the screening, the evaluation of the studies and wrote the review. Tania Lüty supported us with the preparation and drafting of the manuscript. Catharina Sadaghiani gave us methodological support and was involved in critical revision of the review.

Conflicts of Interest: Johannes Naumann receives support from balneology organisations such as Deutscher Heilbäderverband and Heilbäderverband Baden-Württemberg and is a member of these organisations. None of the organisations financed this work. The funding sponsor had no role in the design of the study; the collection, analyses, or interpretation of data; in writing the manuscript, or in the decision to publish the results. The authors declare no conflict of interest. Diana Biehler received support from Verband Deutscher Mineralbrunnen.

\section{Reference}

1. Gesundheitssurvey Prävalenz häufiger Erkrankungen http://www.gbe-bund.de/gbe10/ergebnisse.prc_tab?fid=24742\&suchstring=Diabetes\&query_id=\&sprache= D\&fund_ty $=T A B \& m e t h o d e=3 \& v t=1 \& v e r w a n d t e=1 \&$ page_ret $=0 \&$ seite $=1 \& p \_l f d \_n r=75 \& p \_n e w s=\& p \_s p r a c$ hkz=D\&p_uid=gast\&p_aid=75552896\&hlp_nr=3\&p_janein=J\#SEARCH=\%2522Diabetes\%2522 (accessed Apr 13, 2017). 
2. Gesundheitssurvey, K. Krankheitskosten in Mio. EUR für Deutschland http://www.gbe-bund.de/oowa921-install/servlet/oowa/aw92/dboowasys921.xwdevkit/xwd_init?gbe.isgbet ol/xs_start_neu/\&p_aid=3\&p_aid=15251423\&nummer=553\&p_sprache=D\&p_indsp=-\&p_aid=10356835 (accessed Apr 13, 2017).

3. American Diabetes Association. 5. Prevention or delay of type 2 diabetes. Diabetes Care 2017, 40, S44-S47, DOI:10.2337/dc17-S008.

4. $\mathrm{Hu}, \mathrm{F}$. B. Resolved: there is sufficient scientific evidence that decreasing sugar-sweetened beverage consumption will reduce the prevalence of obesity and obesity-related diseases. Obes. Rev. Off. J. Int. Assoc. Study Obes. 2013, 14, 606-619, DOI:10.1111/obr.12040.

5. Armstrong, L. E. Challenges of linking chronic dehydration and fluid consumption to health outcomes. Nutr. Rev. 2012, 70 Suppl 2, S121-S127, DOI:10.1111/j.1753-4887.2012.00539.x.

6. Williams, R. S.; Heilbronn, L. K.; Chen, D. L.; Coster, A. C. F.; Greenfield, J. R.; Samocha-Bonet, D. Dietary acid load, metabolic acidosis and insulin resistance - lessons from cross-sectional and overfeeding studies in humans. Clin. Nutr. Edinb. Scotl. 2016, 35, 1084-1090, DOI:10.1016/j.clnu.2015.08.002.

7. Souto, G.; Donapetry, C.; Calviño, J.; Adeva, M. M. Metabolic acidosis-induced insulin resistance and cardiovascular risk. Metab. Syndr. Relat. Disord. 2011, 9, 247-253, DOI:10.1089/met.2010.0108.

8. Rasic-Milutinovic, Z.; Perunicic-Pekovic, G.; Jovanovic, D.; Gluvic, Z.; Cankovic-Kadijevic, M. Association of blood pressure and metabolic syndrome components with magnesium levels in drinking water in some Serbian municipalities. J. Water Health 2012, 10, 161-169, DOI:10.2166/wh.2012.028.

9. Carroll, H. A.; Davis, M. G.; Papadaki, A. Higher plain water intake is associated with lower type 2 diabetes risk: a cross-sectional study in humans. Nutr. Res. N. Y. N 2015, 35, 865-872, DOI:10.1016/j.nutres.2015.06.015.

10. Hernández-Cordero, S.; González-Castell, D.; Rodríguez-Ramírez, S.; Villanueva-Borbolla, M. Á.; Unar, M.; Barquera, S.; González de Cossío, T.; Rivera-Dommarco, J.; Popkin, B. M. Design and challenges of a randomized controlled trial for reducing risk factors of metabolic syndrome in Mexican women through water intake. Salud Publica Mex. 2013, 55, 595-606.

11. Imhof, A.; Plamper, I.; Maier, S.; Trischler, G.; Koenig, W. Effect of drinking on adiponectin in healthy men and women: a randomized intervention study of water, ethanol, red wine, and beer with or without alcohol. Diabetes Care 2009, 32, 1101-1103, DOI:10.2337/dc08-1723.

12. Thornton, S. N. Increased hydration can be associated with weight loss. Front. Nutr. 2016, 3, 18, DOI:10.3389/fnut.2016.00018.

13. Sengupta, P. Potential health impacts of hard water. Int. J. Prev. Med. 2013, 4, 866-875.

14. Torsdottir, I.; Andersson, H. Effect on the postprandial glycaemic level of the addition of water to a meal ingested by healthy subjects and type 2 (non-insulin-dependent) diabetic patients. Diabetologia 1989, 32, 231235.

15. Gregersen, S.; Rasmussen, O.; Winther, E.; Hermansen, K. Water volume and consumption time: influence on the glycemic and insulinemic responses in non-insulin-dependent diabetic subjects. Am. J. Clin. Nutr. 1990, 52, 515-518.

16. Toxqui, L.; Vaquero, M. P. An intervention with mineral water decreases cardiometabolic risk biomarkers. A crossover, randomised, controlled trial with two mineral waters in moderately hypercholesterolaemic adults. Nutrients 2016, 8, 400, DOI:10.3390/nu8070400.

17. Schoppen S.; Sánchez-Muniz F. J.; Pérez-Granados M.; Gómez-Gerique J. A. ; Sarriá B.; Navas-Carretero S.; Pilar Vaquero M. Does bicarbonated mineral water rich in sodium change insulin sensitivity of postmenopausal women? Nutr Hosp. 2007, 22, 538-544. 
18. Madjd, A.; Taylor, M. A.; Delavari, A.; Malekzadeh, R.; Macdonald, I. A.; Farshchi, H. R. Beneficial effects of replacing diet beverages with water on type 2 diabetic obese women following a hypo-energetic diet: A randomized, 24-week clinical trial. Diabetes Obes. Metab. 2017, 19, 125-132, DOI:10.1111/dom.12793.

19. Gutenbrunner, C. Kontrollierte Studie über die Wirkung einer Haustrinkkur mit einem Natrium-Hydrogencarbonat-Säuerling auf die Blutzuckerregulation bei gesunden Versuchspersonen. Phys. Med. Rehabil. Kurortmed. 1993, 3, 108-110.

20. Murakami, S.; Goto, Y.; Ito, K.; Hayasaka, S.; Kurihara, S.; Soga, T.; Tomita, M.; Fukuda, S. The consumption of bicarbonate-rich mineral water improves glycemic control. Evid.-Based Complement. Altern. Med. ECAM 2015, 2015, 824395, DOI:10.1155/2015/824395.

21. Pérez-Granados, A. M.; Navas-Carretero, S.; Schoppen, S.; Vaquero, M. P. Reduction in cardiovascular risk by sodium-bicarbonated mineral water in moderately hypercholesterolemic young adults. J. Nutr. Biochem. 2010, 21, 948-953, DOI:10.1016/j.jnutbio.2009.07.010.

22. Schorr, U.; Distler, A.; Sharma, A.M. Effect of sodium chloride- and sodium bicarbonate-rich mineral water on blood pressure and metabolic parameters in elderly normotensive individuals: a randomized double-blind crossover trial. J. Hypertens. 1996, 14, 131-135.

23. Roussel, R.; Fezeu, L.; Bouby, N.; Balkau, B.; Lantieri, O.; Alhenc-Gelas, F.; Marre, M.; Bankir, L.; D.E.S.I.R. Study Group. Low water intake and risk for new-onset hyperglycemia. Diabetes Care 2011, 34, 2551-2554, DOI:10.2337/dc11-0652.

24. Pan, A.; Malik, V. S.; Schulze, M. B.; Manson, J. E.; Willett, W. C.; Hu, F. B. Plain-water intake and risk of type 2 diabetes in young and middle-aged women. Am. J. Clin. Nutr. 2012, 95, 1454-1460, DOI:10.3945/ajcn.111.032698.

25. Carroll, H. A.; Betts, J. A.; Johnson, L. An investigation into the relationship between plain water intake and glycated $\mathrm{Hb}(\mathrm{HbA1c})$ : a sex-stratified, cross-sectional analysis of the UK National Diet and Nutrition Survey (2008-2012). Br. J. Nutr. 2016, 1-11, DOI:10.1017/S0007114516003688.

26. An, R.; McCaffrey, J. Plain water consumption in relation to energy intake and diet quality among US adults, 2005-2012. J. Hum. Nutr. Diet. Off. J. Br. Diet. Assoc. 2016, 29, 624-632, DOI:10.1111/jhn.12368.

27. Basu, S.; McKee, M.; Galea, G.; Stuckler, D. Relationship of soft drink consumption to global overweight, obesity, and diabetes: a cross-national analysis of 75 countries. Am. J. Public Health 2013, 103, 2071-2077, DOI:10.2105/AJPH.2012.300974.

28. Bellasi, A.; Di Micco, L.; Santoro, D.; Marzocco, S.; De Simone, E.; Cozzolino, M.; Di Lullo, L.; Guastaferro, P.; Di Iorio, B.; UBI study investigators. Correction of metabolic acidosis improves insulin resistance in chronic kidney disease. BMC Nephrol. 2016, 17, 158, DOI:10.1186/s12882-016-0372-x.

29. Farwell, W. R.; Taylor, E. N. Serum bicarbonate, anion gap and insulin resistance in the National Health and Nutrition Examination Survey. Diabet. Med. J. Br. Diabet. Assoc. 2008, 25, 798-804, DOI:10.1111/j.1464-5491.2008.02471.x.

30. Mandel, E. I.; Curhan, G. C.; Hu, F. B.; Taylor, E. N. Plasma bicarbonate and risk of type 2 diabetes mellitus. CMAJ Can. Med. Assoc. J. 2012, 184, E719-E725, DOI:10.1503/cmaj.120438.

31. Pereira, C. D.; Severo, M.; Araújo; J. R; Guimarães, J. T.; Pestana, D.; Santos, A.; Ferreira, R.; Ascensão, A.; Magalhães, J.; Azevedo, I.; Monteiro, R.; Martins, M. J. Relevance of a hypersaline sodium-rich naturally sparkling mineral water to the protection against metabolic syndrome induction in fructose-fed Sprague-Dawley rats: A biochemical, metabolic, and redox approach. Int. J. Endocrinol. 2014, 2014, DOI:10.1155/2014/384583. 
32. Das, U. N. Renin-angiotensin-aldosterone system in insulin resistance and metabolic syndrome. J. Transl. Intern. Med. 2016, 4, 66-72, DOI:10.1515/jtim-2016-0022.

33. Guclu, A.; Erdur, F. M.; Turkmen, K. The emerging role of sirtuin 1 in cellular metabolism, diabetes mellitus, diabetic kidney disease and hypertension. Exp. Clin. Endocrinol. Diabetes Off. J. Ger. Soc. Endocrinol. Ger. Diabetes Assoc. 2016, 124, 131-139, DOI:10.1055/s-0035-1565067.

34. Rodgers, J. T.; Lerin, C.; Haas, W.; Gygi, S. P.; Spiegelman, B. M.; Puigserver, P. Nutrient control of glucose homeostasis through a complex of PGC-1 $\alpha$ and SIRT1. Nature 2005, 434, 113-118, DOI:10.1038/nature03354.

35. Pereira, C. D.; Severo, M.; Neves, D.; Ascensão, A.; Magalhães, J.; Guimarães, J. T.; Monteiro, R.; Martins, M. J. Natural mineral-rich water ingestion improves hepatic and fat glucocorticoid-signaling and increases sirtuin 1 in an animal model of metabolic syndrome. Horm. Mol. Biol. Clin. Investig. 2015, 21, 149-157, DOI:10.1515/hmbci-2014-0032.

36. Pereira, C. D.; Passos, E.; Severo, M.; Vitó, I.; Wen, X.; Carneiro, F.; Gomes, P.; Monteiro, R.; Martins, M. J. Ingestion of a natural mineral-rich water in an animal model of metabolic syndrome: effects in insulin signalling and endoplasmic reticulum stress. Horm. Mol. Biol. Clin. Investig. 2016, DOI:10.1515/hmbci-2015-0033.

37. Gommers, L. M. M.; Hoenderop, J. G. J.; Bindels, R. J. M.; de Baaij, J. H. F. Hypomagnesemia in type 2 diabetes: A vicious circle? Diabetes 2016, 65, 3-13, DOI:10.2337/db15-1028.

38. Guerrero-Romero, F.; Simental-Mendía, L. E.; Hernández-Ronquillo, G.; Rodriguez-Morán, M. Oral magnesium supplementation improves glycaemic status in subjects with prediabetes and hypomagnesaemia: A double-blind placebo-controlled randomized trial. Diabetes Metab. 2015, 41, 202-207, DOI:10.1016/j.diabet.2015.03.010.

39. Mooren, F. C.; Krüger, K.; Völker, K.; Golf, S. W.; Wadepuhl, M.; Kraus, A. Oral magnesium supplementation reduces insulin resistance in non-diabetic subjects - a double-blind, placebo-controlled, randomized trial. Diabetes Obes. Metab. 2011, 13, 281-284, DOI:10.1111/j.1463-1326.2010.01332.x.

40. Simental-Mendía, L. E.; Sahebkar, A.; Rodríguez-Morán, M.; Guerrero-Romero, F. A systematic review and meta-analysis of randomized controlled trials on the effects of magnesium supplementation on insulin sensitivity and glucose control. Pharmacol. Res. 2016, 111, 272-282, DOI:10.1016/j.phrs.2016.06.019.

41. Lecube, A.; Baena-Fustegueras, J. A.; Fort, J. M.; Pelegri, D.; Hernandez, C.; Simo, R. Diabetes is the main factor accounting for hypomagnesemia in obese subjects. PLoS ONE 2012, 7, DOI:10.1371/journal.pone.0030599.

42. Kieboom, B. C. T.; Ligthart, S.; Dehghan, A.; Kurstjens, S.; de Baaij, J. H. F.; Franco, O. H.; Hofman, A.; Zietse, R.; Stricker, B. H.; Hoorn, E. J. Serum magnesium and the risk of prediabetes: a population-based cohort study. Diabetologia 2017, 60, 843-853, DOI:10.1007/s00125-017-4224-4.

43. Dong, J.-Y.; Xun, P.; He, K.; Qin, L.-Q. Magnesium intake and risk of type 2 diabetes: meta-analysis of prospective cohort studies. Diabetes Care 2011, 34, 2116-2122, DOI:10.2337/dc11-0518.

44. Fang, X.; Han, H.; Li, M.; Liang, C.; Fan, Z.; Aaseth, J.; He, J.; Montgomery, S.; Cao, Y. Dose-response relationship between dietary magnesium intake and risk of type 2 diabetes mellitus: A systematic review and meta-regression analysis of prospective cohort studies. Nutrients 2016, 8, DOI:10.3390/nu8110739.

45. Dibaba, D. T.; Xun, P.; Fly, A. D.; Yokota, K.; He, K. Dietary magnesium intake and risk of metabolic syndrome: a meta-analysis. Diabet. Med. J. Br. Diabet. Assoc. 2014, 31, 1301-1309, DOI:10.1111/dme.12537.

46. Mooren, F. C. Magnesium and disturbances in carbohydrate metabolism. Diabetes Obes. Metab. 2015, 17, 813823, DOI:10.1111/dom.12492. 
47. Ha, B. G.; Park, J.-E.; Shin, E. J.; Shon, Y. H. Modulation of glucose metabolism by balanced deep-sea water ameliorates hyperglycemia and pancreatic function in streptozotocin-induced diabetic mice. PLOS ONE 2014, 9, e102095, DOI:10.1371/journal.pone.0102095.

48. Dibaba, D. T.; Xun, P.; He, K. Dietary magnesium intake is inversely associated with serum C-reactive protein levels: meta-analysis and systematic review. Eur. J. Clin. Nutr. 2014, 68, 510-516, DOI:10.1038/ejen.2014.7.

49. Buchanan, T. A.; Xiang, A. H.; Peters, R. K.; Kjos, S. L.; Marroquin, A.; Goico, J.; Ochoa, C.; Tan, S.; Berkowitz, K.; Hodis, H. N.; Azen, S. P. Preservation of pancreatic beta-cell function and prevention of type 2 diabetes by pharmacological treatment of insulin resistance in high-risk hispanic women. Diabetes 2002, 51, 2796-2803.

50. Defronzo, R. A.; Tripathy, D.; Schwenke, D. C.; Banerji, M.; Bray, G. A.; Buchanan, T. A.; Clement, S. C.; Henry, R. R.; Kitabchi, A. E.; Mudaliar, S.; Ratner, R. E.; Stentz, F. B.; Musi, N.; Reaven, P. D.; Gastaldelli, A.; ACT NOW Study. Prediction of diabetes based on baseline metabolic characteristics in individuals at high risk. Diabetes Care 2013, 36, 3607-3612, DOI:10.2337/dc13-0520.

51. Guerrero-Romero, F.; Rodríguez-Morán, M. Magnesium improves the beta-cell function to compensate variation of insulin sensitivity: double-blind, randomized clinical trial. Eur. J. Clin. Invest. 2011, 41, 405-410, DOI:10.1111/j.1365-2362.2010.02422.x.

52. Nair, A. V.; Hocher, B.; Verkaart, S.; van Zeeland, F.; Pfab, T.; Slowinski, T.; Chen, Y.-P.; Schlingmann, K. P.; Schaller, A.; Gallati, S.; Bindels, R. J.; Konrad, M.; Hoenderop, J. G. Loss of insulin-induced activation of TRPM6 magnesium channels results in impaired glucose tolerance during pregnancy. Proc. Natl. Acad. Sci. U. S. A. 2012, 109, 11324-11329, DOI:10.1073/pnas.1113811109.

53. WHO, Regional Office for the Western Pacific. Be smart drink water: a guide for school principals in restricting the sale and marketing of sugary drinks in and around schools. 2016. (available online: http://apps.who.int/iris/handle/10665/208340). 